\title{
The Treatment of the Ebola Virus with Vibrational Herbal Medicine
}

\author{
Almoez LeDin Ellah* \\ The National Center for Research, Egypt \\ *Corresponding author: Almoez LeDin Ellah, The National Center for Research, Egypt
}

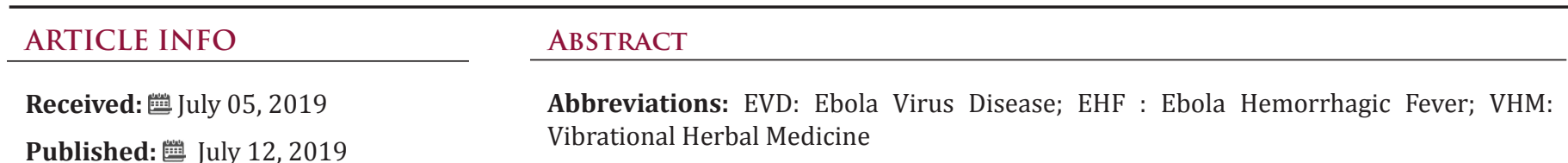

Citation: Almoez LeDin Ellah. The Treatment of the Ebola Virus with Vibrational Herbal Medicine. Biomed J Sci \& Tech Res 19(4)-2019. BJSTR. MS.ID.003325.

\section{Definition}

Ebola virus disease (EVD), also known as Ebola hemorrhagic fever (EHF) or simply Ebola, is a viral hemorrhagic fever of humans and other primates caused by ebolaviruses the disease has a high risk of death, killing between 25 and 90 percent of those infected, with an average of about 50 percent [1]. This is often due to low blood pressure from fluid loss, and typically follows six to sixteen days after symptoms appear [1]. It struck in a huge wave several countries in Africa, and a massive effort was undertaken to find a cure and treat the thousands of afflicted patients. This concern made us interested to test the mechanism of Vibrational Herbal Medicine and whether it will be able to handle such a challenge to cure Ebola. The procedure to proceed in treating an unknown virus using Vibrational Herbal Medicine(VHM ), has been established for several years and we have published several manuscripts dealing with treatment of HIV, MS and other viruses using the VHM technique [2-4].

We obtained a specimen, which was a photograph of one of the patients afflicted by the disease from one of the newspapers, in addition, a photograph of the microscopic shape of the virus. Studying both, we were able to obtain the characteristics of the energy patterns of the virus. This gave us the map to follow to obtain the cure. This photograph gave us the size of the virus based on our assumption of what the unit of the virus maybe, plus we were able to obtain the power of the virus and thus design a sure cure. The virus is very small in size, compared to other viruses such as Hep C but is extremely powerful.

The energy characteristics of the virus have been rechecked with the re-emergence of the virus, and they are as follows:

$$
\begin{aligned}
& Q=-25 \\
& Y n=-25 \\
& Y g=-25 \\
& \Omega=-35 .
\end{aligned}
$$

Based on our research, the size of the virus is $48 \times 1,000,000 \times 10$ to the power of $\mathrm{xxxx}$ units the treatment attacks the energy vibrations of the virus using the Laws of Ancient wisdom [4], the virus is unable to fend off its attack. The energy of the virus is finally eliminated after two days of treatment. The dose of the treatment is two $900 \mathrm{mg}$ after breakfast or lunch for two days. These are sufficient to eliminate all of the virus and its infectious abilities.

The energy characteristics of the cure are as follows:

$$
\begin{aligned}
& Q=90 \\
& Y n=90 \\
& Y g=90 \\
& \Omega=36
\end{aligned}
$$


These values target the energy of the virus in the patient and destroy them very rapidly. We also concluded that there are 9 different strains that will be cured by this treatment. The composition of this treatment is totally herbal with no additives. The only drawback is that it is in capsule form.

\section{References}

1. Ebola virus disease. From Wikipedia, the free encyclopedia.

ISSN: 2574-1241

DOI: 10.26717/BJSTR.2019.19.003325

Almoez LeDin Ellah. Biomed J Sci \& Tech Res

(C) (P) This work is licensed under Creative

Submission Link: https://biomedres.us/submit-manuscript.php
2. Eltouny, Almoez (2019) Treatment of MS using Vibrational Herbal Medicine and the Laws of Ancient Wisdom. New York Science Journal New York.

3. h t t p : / / w w w. fortunejournals.com/archives of-clinical-medical-case-reports/old issues.

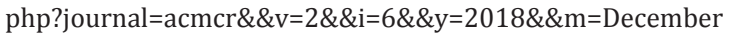

4. Eltouny, Almoez (2001) Laws of Ancient Wisdom. published in Explore Magazine year. 10 Prescott, Arizona.

$\begin{array}{ll}\text { BIOMEDICAL } & \text { Assets of Publishing with us } \\ \text { RESEARCHES } & \text { - Global archiving of articles } \\ & \text { - Immediate, unrestricted online access } \\ & \text { - Rigorous Peer Review Process } \\ \end{array}$

